\title{
Quality assessment of some bottled water produced in Okitipupa, Ondo state, Nigeria
}

Folorunso Femi Adekunle ${ }^{\mathrm{a}}$, Folorunso Aderonke Similoluwa ${ }^{\mathrm{b}}$, Oyebamiji Abel Kolawole $^{\mathrm{c}, \mathrm{e}}$, Akintelu Sunday Adewale d,e* $^{\text {en }}$

${ }^{a}$ Department of Anatomy, Osun State University, Osogbo, Nigeria.

${ }^{b}$ Department of Chemistry, Louisiana State University, Louisiana,USA

${ }^{c}$ Department of Basic Sciences, Adeleke University, P.M.B. 250, Ede, Osun State, Nigeria.

${ }^{d}$ School of Chemistry and Chemical Engineering, Beijing Institute of Technology, Beijing, China. ${ }^{e}$ Department of Pure and Applied Chemistry, Ladoke Akintola University of Technology, PMB 4000 Ogbomoso, Nigeria. akintelusundayadewale@gmail.com

Keywords: physico-chemical parameters, heavy metals, bottled water, atomic absorption spectrophotometer.

The aim of this study was to assess the safety level of some bottled water produced in Okitipupa, Ondo State Nigeria. Several packs of bottled water were obtained from three different manufacturers. Some physicochemical parameters and heavy metals were investigated to assess the quality of the bottle water using standard methods. The results from the physicochemical parameters and heavy metals were in with World Health Organization (WHO) standard for drinking water when compared. This study confirmed that the analyzed bottled water has good quality. Therefore, these bottled water are said to be safe for drinking.

\section{Introduction}

Water is an indispensable resources needed for the existence of all living things including man, water plays important role in body metabolism and proper functioning of the cells. Adequate supply of fresh and clean drinking water is a basic need for all human beings [1]. The prevalence of disease such as typhoid fever, polio, hepatitis, cholera, diarrhoea and bacillary dysentery has been traced to consumption of contaminated water [2]. The physicochemical and bacteriological characteristics of water for human usage are referred to as water quality The realization of the potential health challenges associated with the intake of contaminated water are very imperative due to the danger of water borne diseases [3].

Many sources of drinking water contain some aquatic microbes or contaminants, which might be hazardous to human health if they find their ways into the human body. Therefore, the treatment of drinking water require the removal 
of microbes and contaminates before the water is being used [4].

In an attempt to reduce transmission of contagious diseases such as tuberculosis, typhoid and cholera originating from the usage of public bowls or cups for drinking water, the production of bottled water and sachet water has been encouraged [5]. Also the absence or insufficient distribution of reliable, safe and quality drinking water in the urban areas coupled with easy of transportation of quality drinking water has led to increase in demand and production of bottled water production in Nigeria [6]. Bottled water is the major source of drinking water in Okitipupa and its communities.

The high demand for bottled water has made small-scale entrepreneurs to venture into the production of bottled water without due acquaintance of standard hygienic production practices required. Therefore, a good knowledge on the chemical properties of raw water is important to determine its suitability for usage. Thus, constant analysis of bottled water must be conducted to determine the effectiveness and efficiency of treatment process. This study therefore, intend to examine the safety level of several bottled water produced in Okitipupa in conformity to standards set by National Agency for Food and Drug Administration and Control (NAFDAC).

\section{Materials and methods}

\section{Area of Study}

Okitipupa is a Local Government Area (LGA) in Ondo State of Nigeria (Fig. 1). It lies between latitude $6^{\circ} 25^{\prime}$ and $6^{\circ} 25^{\prime} \mathrm{N}$ and longitude $4^{\circ} 35^{\prime}$ and $4^{\circ} 50^{\prime}$ E. Okitipupa is also within the tropical rainforest zone of Nigeria. It has a land mass of $636 \mathrm{sq} \mathrm{km}$ with 234138 population.

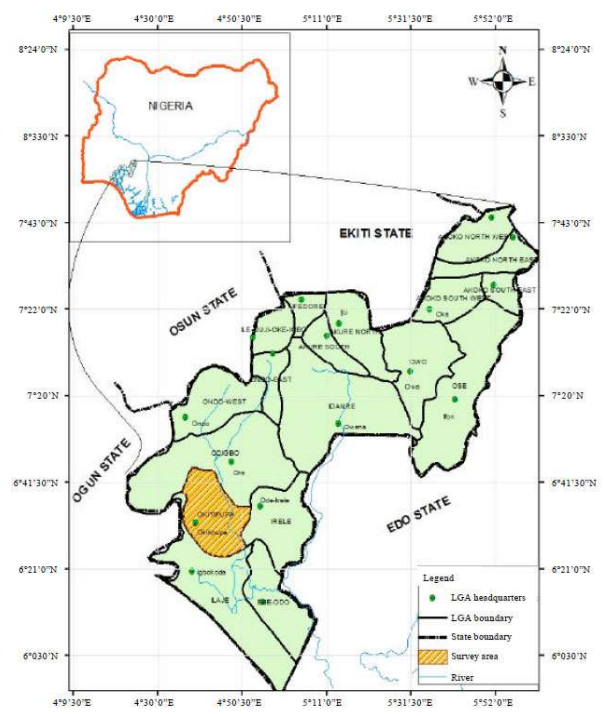

Figure 1. Map of Ondo state showing Okitipupa local government

\section{Sample collection and analysis}

Three (3) different brands of $75 \mathrm{cL}$ bottled water samples certified by NAFDAC were purchased from the study area. Two cartons of each brand of bottled water were purchased and taken to the laboratory for analysis. The samples were stored at room temperature prior analysis.

\section{Water Quality Analyses}

The determination of $\mathrm{pH}$ and Electronic conductivity were done using $\mathrm{pH}$ meter (Orion 4 star) and Electrical conductivity meter (EC 214, 
HANNA instruments) respectively. Chloride $\left(\mathrm{Cl}^{-}\right)$content was determined titrimetrically. EDTA titration method was used for the total hardness determination. UV-VIS Spectrophotometer (Shimadzu 3401) was used to quantify the concentration of Sulphate ( $\mathrm{SO}^{2-}$ ) and Nitrate $\left(\mathrm{NO}^{3-}\right)$. Temperature, total dissolved solid, colour, turbidity, fluoride, chloride sulphate, nitrate and nitrite were estimated using standard methods. Atomic Absorption spectrophotometer (Shimadzu AA-6800 Japan) coupled with air/acetylene flame was used for the determination of the concentration of metals.

\section{Results and Discussion}

\section{Physico-chemical Parameters of the studied bottled water}

\section{Temperature Determination}

The temperature of the bottled water samples ranged from $24.8^{\circ} \mathrm{C}-27.5^{\circ} \mathrm{C}$ as represented in (Table 1). Variations in temperature were observed in all the samples during the period of study, this variation might be attributed to the storage condition of the water as suggested by [7]. However the temperature of the studied bottled water are within WHO limit. Low temperature has been reported to encourage the optimal growth of mesophilic bacteria and other human pathogens. The result obtained were in line with previous studies [8].

\section{Electrical Conductivity (EC) Parameter}

The electrical conductivity values were between 10.2 and $109.2 \mu \mathrm{S} / \mathrm{cm}$ as showed in
(Table 1). Wabayo bottle water has the highest electrical conductivity values among the water samples studied. Electrical conductivity of water helps in estimating the availability of ions of carbonate, bicarbonates, chloride, sulphate, nitrate, sodium, potassium, and magnesium in water sample [9]. The presence of these chemical constituents enhance the electrical conductivity of water.

The WHO maximum EC value for drinking water was $500 \mu \mathrm{S} / \mathrm{cm}$. Compared to these standards, all the samples had electrical conductivity values below the miximum permissible limit. This is a good indication that the bottle water contains minimum quantity of dissolved ionic salts rendering it safe for drinking.

\section{pH Determination}

$\mathrm{pH}$ values of the bottled water were presented in (Table 1). All the samples have $\mathrm{pH}$ values within the recommended range of 6.566.8 for drinking water [10]. This indicated that they are safe for human consumption. The highest $\mathrm{pH}$ value was observed in Wabayo and Jah reward bottled 6.8 while Comfy bottled water samples obtained in the month of July has the lowest $\mathrm{pH}$ value of 6.6. Water with low or high $\mathrm{pH}$ value are regarded to be problematic because such water can damage metal pipes and other storage devices [11]. Bitter test and corrosion has been reported as potential health effects of water with $\mathrm{pH}$ values outside the WHO limit [12].

\section{Total Dissolved Solids (TDS) Parameter}


The TDS values was in the range of $6.4 .60-8.7 \mathrm{mg} / \mathrm{L}$ in this study as described in (Table 1). The bottled water samples studied had their total dissolved solids values within the WHO standard of $500 \mathrm{mg} / \mathrm{L}$ for drinking water. Since the TDS of the samples are less than 500 $\mathrm{mg} / \mathrm{L}$ this suggests that the water might not pose any laxative effects on consumers [13]. However, high TDS values in drinking water has been reported to cause goiter, hypertension, ischemic, heart disease which are regarded as health challenges [14]. Increase in TDS value above the permissible limit has been reported to impart a bad odour or taste to drinking water and also cause scaling of pipes [15]

\section{Color Estimation}

The color of the bottle water samples measured are in the range from 0 to $0.1 \mathrm{HU}$ (Table 1). The highest colour measurement was observed in the samples obtained in the month of April for Comfy and Jah reward bottle water. Other bottled water samples has their colour to be $0 \mathrm{HU}$ as illustrated in Table. Water colour has been linked to discharge from soap and detergent factory that uses different coloring materials in the manufacturing process or due to the presence of organic matter such as humid substances and metals like iron and manganese [12]. Drinking water is expected to be colorless [10].Colored water are not aesthetically acceptable to the public. The low values obtained from the color analysis suggest that the water has been well purified and hence good for drinking.

\section{Turbidity Determination}

The turbidity values for the studied bottled water samples was 0 NTU as showed in (Table 1). This implies that the bottled water has their turbidity values within the WHO standard of 5.0 NTU for Drinking water. The low values of turbidity are in line with the physical observation of the samples which revealed clear and colorless without particulate matter. The result of turbidity values in this study is similar to that obtained by [16].

\section{Fluoride Concentration}

Fluoride concentrations are in the range of 0.01 to $0.02 \mathrm{mg} / \mathrm{L}$. Highest concentration of fluoride were found in Comfy and Jah reward bottled water obtained in April, other bottled water have their fluoride values to be $0.013 \mathrm{mg} / \mathrm{L}$ except for all the bottled water obtained in the month of June as showed in (Table 1). The concentrations of fluoride in water and foods are always low. Report had shown that Underground water has high concentration of fluoride compared to fresh water [12]. The low concentrations of fluoride in these bottle water samples is an indication that children expose to this drinking water may likely not get the required fluoride to prevent dental decay since fluoride is essential in drinking water to prevent dental problems [17].

\section{Sulphate, Nitrite and Nitrate Concentrations}

The concentrations of sulphate, nitrite and nitrate in the samples were below detection limit except for Comfy and Jah reward bottled 
water samples obtained in the month of June where the concentration of sulphate were 1.7 and $1.9 \mathrm{mg} / \mathrm{L}$ respectively (Table 1 ). However the concentration of sulphate, nitrite and nitrate are still within the WHO specification for drinking water. The concentrations of sulphate and nitrate in these bottled water corroborates with previous studies reported by [18]. Ingestion of sulphate in large quantity has been found to be responsible for catharsis and gastrointestinal irritation [19]. Excess intake of nitrate have caused many health defects among which we are; cancer, hypertension, increased infant mortality and changes in the immune system [20].

\section{Total hardness Determination}

Total hardness values in all the samples ranges from 2.5 to $30 \mathrm{mg} \mathrm{L}^{-1}$ as showed in (Table 1). Hardness value from 70 to $120 \mathrm{mg} \mathrm{L}^{-1}$ is regarded as moderately hard water [21]. Water hardness values greater than $500 \mathrm{mg} \mathrm{L}^{-1}$ are unacceptable for most domestic purposes [10]. The concentrations of total hardness in this study were below the limit (500 $\left.\mathrm{mg} \mathrm{L}^{-1}\right)$ set by WHO for drinking water. Water with high hardness value might cause some adverse health issues in humans [10]. High water hardness has been documented to cause cardiovascular health issue [22].
Concentrations of Heavy metals in the studied bottled water

\section{Manganese Concentration}

Manganese concentrations in bottle water recorded in this study was $0.01 \mathrm{mg} / \mathrm{L}$ all through except for samples obtained from Comfy bottle water and Jah reward bottle water factories in the month of June as presented in (Table 2). The studied bottle water has concentrations of manganese to be within the acceptable level 0.05 $\mathrm{mg} / \mathrm{L}$ for drinking water [23]. Intake of high concentration of Manganese above $0.4 \mathrm{mg} / \mathrm{l}$ leads to death WHO, (2014).

\section{Iron Concentration}

The concentration of iron in the bottled water samples are below detention limit except for Jah reward bottle water obtained in the month of June with a concentration of $0.01 \mathrm{mg} / \mathrm{L}$ as showed in (Table 2). The value was below the maximum contaminant level of $<0.3 \mathrm{mg} / 1$ which is an acceptable level for drinking water [23]. However, concentrations of iron in the range of $0.3-1.0 \mathrm{mg} / \mathrm{l}$ are satisfactory level but may lead to staining and bad taste. Previous study revealed that high concentrations of iron above $0.3 \mathrm{mg} / 1$ give rise to consumer complaints due to its ability to discolor aerobic waters [24].This result indicates that the studied bottled water samples are not contaminated with iron.

Copper: The concentrations of copper in the bottled water samples under the study are below detention limit except for the sample obtained from Comfy bottle water in the month of June 
Table 1. Physicochemical analysis of the studied bottled water

\begin{tabular}{|c|c|c|c|c|c|c|c|c|c|c|c|c|c|}
\hline \multicolumn{14}{|c|}{ PHYSICOCHEMICAL ANALYSIS } \\
\hline & \multicolumn{4}{|c|}{$\begin{array}{l}\text { WABAYO BOTTLED } \\
\text { WATER }\end{array}$} & \multicolumn{4}{|c|}{ COMFY BOTTLED WATER } & \multicolumn{4}{|c|}{$\begin{array}{l}\text { JAH REWARD } \\
\text { BOTTLED WATER }\end{array}$} & \multirow[t]{2}{*}{$\begin{array}{l}\text { WHO } \\
\text { LIMIT }\end{array}$} \\
\hline $\begin{array}{l}\text { PARAMET } \\
\text { ERS }\end{array}$ & APR & JUN & JUL & $\begin{array}{l}\text { MEAN } \\
\pm \text { S.D }\end{array}$ & APR & JUN & JUL & $\begin{array}{l}\text { MEAN } \pm \text { S. } \\
\text { D }\end{array}$ & APR & JUN & JUL & $\begin{array}{l}\text { MEA } \\
\mathbf{N} \pm \text { S.D }\end{array}$ & \\
\hline Temperature & 27 & 27.5 & 26 & $\begin{array}{l}26.83 \pm \\
0.02\end{array}$ & 25 & 26 & 24.8 & $25.27 \pm 0.0$ & 26 & 27 & 25.8 & 26.27 & - \\
\hline $\begin{array}{l}\text { Electrical } \\
\text { Conductivity, } \\
\text { us/cm }\end{array}$ & 98.6 & 118 & $\begin{array}{l}109 . \\
2\end{array}$ & $\begin{array}{l}108.6 \pm \\
0.18\end{array}$ & 12.4 & 16.3 & 14.5 & $14.4 \pm 0.27$ & 10.2 & 19.9 & 16.3 & 15.47 & 500 \\
\hline $\mathrm{pH}$ & 6.8 & 6.8 & 6.8 & $\begin{array}{l}06.8 \pm 0 . \\
00\end{array}$ & 6.7 & 6.7 & 6.56 & $6.65 \pm 0.02$ & 6.8 & 6.8 & 6.8 & 6.8 & $\begin{array}{l}6.5- \\
8.5\end{array}$ \\
\hline TDS mg/L & 6.5 & 6.5 & 6.4 & $\begin{array}{l}6.47 \pm 0 . \\
02\end{array}$ & 7.6 & 7.2 & 8.7 & $7.83 \pm 0.04$ & 6.5 & 6.4 & 6.4 & 6.4 & 500 \\
\hline Colour units & 0 & 0 & 0 & $0 \pm 0.00$ & 0.1 & 0 & 0 & & 0.1 & 0 & 0 & 0.03 & $5-20$ \\
\hline $\begin{array}{l}\text { Turbidity } \\
\text { N.T.U }\end{array}$ & 0 & 0 & 0 & $0 \pm 0.00$ & 0 & 0 & 0 & $0.00 \pm 0.00$ & 0 & 0 & 0 & 0.00 & 5 \\
\hline Fluoride $\mathrm{mg} / \mathrm{L}$ & 0.01 & ND & 0.01 & $0 \pm 0.00$ & 0.02 & ND & 0.01 & 0.02 & 0.02 & ND & 0.01 & 0.02 & 1.5 \\
\hline $\begin{array}{l}\text { Sulphate, } \\
\mathrm{mg} / \mathrm{L}\end{array}$ & ND & ND & ND & - & ND & 0.7 & ND & 0.7 & ND & 1.9 & ND & 1.9 & 500 \\
\hline Nitrate $\mathrm{mg} / \mathrm{L}$ & ND & ND & $\mathrm{ND}$ & - & ND & ND & ND & & ND & ND & ND & - & 20 \\
\hline Nitrite $\mathrm{mg} / \mathrm{L}$ & ND & ND & $\mathrm{ND}$ & - & ND & $\mathrm{ND}$ & ND & & ND & ND & $\mathrm{ND}$ & - & 3.0 \\
\hline $\begin{array}{l}\text { Total } \\
\text { hardness, } \\
\mathrm{mg} / \mathrm{L}\end{array}$ & 4 & 3.5 & 2.5 & $\begin{array}{l}3.33 \pm 0 . \\
20\end{array}$ & 7.7 & 6.2 & 3.1 & $5.67 \pm 0.48$ & 14.4 & 30 & 15.2 & $\begin{array}{l}19.87 \\
\pm 1.03\end{array}$ & $50-150$ \\
\hline
\end{tabular}


Table 2. Heavy matals analysis of the studied bottled water

\begin{tabular}{|c|c|c|c|c|c|c|c|c|c|c|c|c|c|}
\hline \multicolumn{14}{|c|}{ HEAVY MATALS ANALYSIS } \\
\hline & \multicolumn{4}{|c|}{$\begin{array}{l}\text { WABAYO BOTTLED } \\
\text { WATRER }\end{array}$} & \multicolumn{4}{|c|}{ COMFY BOTTLED WATRER } & \multicolumn{4}{|c|}{$\begin{array}{l}\text { JAH REWARD BOTTLED } \\
\text { WATRER }\end{array}$} & \multirow[t]{2}{*}{$\begin{array}{l}\text { WHO } \\
\text { LIMIT }\end{array}$} \\
\hline HEAVY METALS & APR & JUN & JUL & $\begin{array}{l}\text { MEA } \\
\mathbf{N} \pm \mathbf{S} . \\
\text { D }\end{array}$ & APR & JUN & JUL & $\begin{array}{l}\text { MEAN } \\
\pm \text { S.D }\end{array}$ & $\overline{A P R}$ & JUN & JUL & $\begin{array}{l}\text { MEA } \\
\text { N } \pm \text { S. } \\
\text { D }\end{array}$ & \\
\hline $\begin{array}{l}\text { Manganese } \\
\mathrm{mg} / \mathrm{L}\end{array}$ & 0.01 & 0.01 & 0.01 & $\begin{array}{l}0.01 \pm \\
0.00\end{array}$ & 0.01 & ND & 0.01 & $\begin{array}{l}0.01 \pm \\
0.0\end{array}$ & 0.01 & $\mathrm{ND}$ & 0.01 & $\begin{array}{l}0.01 \pm \\
0.0\end{array}$ & 0.5 \\
\hline Iron mg/L & ND & ND & ND & 0 & ND & ND & ND & 0 & ND & 0.01 & ND & & $<0.3$ \\
\hline Copper mg/L & ND & ND & ND & 0 & ND & 0.01 & ND & & ND & ND & ND & 0 & 0.1 \\
\hline Lead mg/L & ND & ND & $\mathrm{ND}$ & 0 & ND & ND & ND & 0 & ND & ND & ND & 0 & 0.01 \\
\hline $\begin{array}{l}\text { Cadmium } \\
\mathrm{mg} / \mathrm{L}\end{array}$ & ND & ND & ND & 0 & ND & ND & ND & 0 & ND & ND & ND & 0 & 0.003 \\
\hline Arsenic mg/L & ND & ND & $\mathrm{ND}$ & 0 & ND & ND & ND & 0 & ND & $\mathrm{ND}$ & ND & 0 & 0.05 \\
\hline Barium mg/L & ND & ND & ND & 0 & ND & ND & ND & 0 & ND & ND & ND & 0 & 2 \\
\hline Mercury mg/L & ND & ND & ND & 0 & ND & ND & ND & 0 & ND & ND & ND & 0 & 0.002 \\
\hline Cyanide mg/L & ND & ND & ND & 0 & ND & ND & ND & 0 & ND & ND & ND & 0 & 0.2 \\
\hline
\end{tabular}

with a concentration of $0.01 \mathrm{mg} / \mathrm{L}$ as showed in the bottle water study can be considered (Table 2). However, the concentrations of copper wholesome with respect to copper content. are within the limit recommended set by WHO $(0.1 \mathrm{mg} / \mathrm{L})$ for drinking water. This shows that copper concentrations in the bottle water samples Lead, Cadmium Arsenic, Barium, Mercury and Cyanide

The concentrations of lead, cadmium were generally low. Considering the guideline, arsenic, barium, mercury and cyanide were below detection limit in this study as showed in 
(Table 2). Cases of lead poisoning have been reported in Zamfara state, Nigeria and conclusion has been made that lead contamination in water and environment are the cause of several death of people and animals [25]. High concentrations of cadmium has been traced to chronic kidney dysfunction, inducing cell injury and interfering of cadmium with calcium regulation in biological systems in human leads to death [26]. However, water with concentrations of cadmium with $\mathrm{pH}$ less than 4.5 is a major health concern [24]. This finding is in agreement with previous study [2729].

\section{Conclusion}

The study showed that the physicochemical parameters and concentration of heavy metals were within (WHO) regardless of the brand name of the bottled water. The concern however was the low concentration of fluoride in all brands of studied bottled water which might result to teeth decay especially in children. Continuous assessment of water quality to ensure effectiveness of the treatment, processes and regulations are needed to ensure that water quality meets the set standards for bottled water since bottled water is one of the major sources of drinking water in Okitipupa and Nigeria as a whole.

\section{References}

[1] Edema MO, Atayese AO, Bankole MO. Pure Water Syndrome: Bacteriological quality of sachet- packed drinking water sold In Nigeria. Afr. J. Food, Agricult. Nutr. Dev. 2011; 11(1):4595-4609
[2] Emre B, Cem OE, Zübeyir T. Physicochemical properties of both drinking and domestic waters in Corum. Int. J. Sci, Lett. 2019; 1(1): 42-55.

[3] Fapetu OM. Comparative Analysis of Different Sources of Drinking Water in Abeokuta South L.G A., Ogun State(B.Sc. Thesis) UNAAB Abeokuta. 2000; 44-45.

[4] Fawole MO, Oso BA. Laboratory manual of Microbiology: Revised edition spectrum books Ltd Ibadan. 2001; 127-128

[5] Danso-Boateng E, Frimpong IK. Quality analysis of plastic sachet and bottled water brands produced or sold in Kumasi, Ghana. Int. J. Dev. Sust. 2013; (2)4: 2222-2232

[6] Okonko IO, Adejoye OD, Ogunnusi TA, Fajobi EA,Shittu OB. Microbiological and physicochemical analysis of different water samples used for domestic purposes in Abeokuta and Ojota, Lagos State, Nigeria. Afr. J. Biotechn. 2008; (7)5:617-621

[7] Waziri FM, Bomai AM. The PhysicoChemical Quality of Sachet Water in Damaturu, Yobe State, Nigeria, Int. J. Bas. App. Chem. Sci. 2012; (2)3: 2124

[8] Pardeshi BM. Screening of physicochemical parameters of water samples from pune area, India. J. Emer. Techn. Innov. Res. 2019; 6(5): 63-69.

[9] Orebiyi E, Awomeso J, Idowu O. Assessment of pollution hazards of shallow well water in Abeokuta and environs, southwest, Nigeria. Amer. J. Envir. sci. 2010; 6(1):50-56.

[10] World Health Organization (WHO). Guidelines for drinking water quality.4th ed.; WHO Press: World Health Organization, 20 Avenue Appia, 1211 Geneva 27, Switzerland. 2011; PP: 1-518.

[11] Bujar DH, Reka AA, Ismaili M, Shabani A. Physico-chemical quality assessment of the drinking water in the summer season in Tetova. J. Chem. Bio. Phy. Sci. 2013; 3: 2352-2360.

[12] Tadesse M, Tsegaye D, Girma G. Assessment of the level of some physico-chemical 
parameters and heavy metals of Rebu river in oromia region, Ethiopia. MOJ. Bio. Med. 2018; 3(3):99-118

[13] Peter C, Victor N, Eltony M, Tumo K. Noel VTC. Situational analysis of physico-chemical, biochemical and microbiological quality of water along Mohokare River, Lesotho. Egyp. J. Aqua. Res. 2019; 45(2): 45-51.

[14] Akpoborie IA, Ehwarimo A. Quality of Packaged Drinking Water Produced in Warri Metropolis and Potential Implications for Public Health. J.Environ. Chem. Ecotox. 2012; (4)11:195-202.

[15] Ackah M, Agyemang O, Anim AK, Osei J, Bentil, NO, Kpattah L. Assessment of groundwater quality for drinking and irrigation: The case study of TeimanOyarifa Community, Ga East Municipality.Ghana Proceedings. Int. Aca. Eco.Environ. Sci. (2011; 3(4):186194.

[16] Akpen GD, Kpoghol IS, Oparaku LA. Quality Assessment of Sachet and Bottled Water Sold in Gboko, Benue State, Nigeria. Nig. J. Techn. 2018; 37(1): $241-248$

[17] Adelana SMA, Olasehinde PI. An Assessment of Chemical Quality of Bottled Drinking Water In Nigeria. J. Nig. Assoc. Hydrog. (2002; 13:12-18

[18] Ramakrishnaiah CR, Sadashivaiah C, Ranganna G. Assessment of water quality index for the groundwater in Tumkur Taluk, Karnataka State India. Euro. J. Chem. 2009; 6(2):523-530.

[19] Park K. Textbook of preventive and social medicine, 20th edition, BanarsidasBhanot publishers, Jabalpur, India; 2009; pp 112-115

[20] Villaueva CM, Kogevines M, Cordier S, Templeton MR, Vermeulen R, Nuckols JR. Assessing exposure and healthconsequences of chemicals in drinking water; current state of knowledge and research needs. Environ. Hlth Pers. 2014; 122(3):1-10.

[21] Environment Canada Surface water quality in Canada - an overview. Water Quality Branch, Inland. 1977.

[22] Marque S, Jacqmin-Gadda H, Dartigues JF, Commenges D. Cardiovascular mortality and calcium andmagnesium in drinking water: an ecological study in elderly people. Eur. J. Epidemiol. 2003;18(4):305-9.

[23] United State Environmental Protection Agency (USEPA). List of contaminants and their maximum contaminant level (MCLs). URL: their maximum contaminant level (MCLs). URL: \#List. 2010. Accessed on 10-02-2019.

[24] World Health Organisation (WHO) Guidelines for drinking-water quality, 3rd edn., World Health Organization, Geneva. 2004.

[25] Majiya MH, Abdulmumin AN, Sallau MS, Hussaini MM, Mohammed AK. Zamfara lead poisoning saga: Comparison of lead contamination level of water samples and lead poisoning in Bagega Artisanal gold mining district. Nig. J. Chem. Pharm. Res. 2015; 7(3):7-12

[26] Woodworth JC, Pascoe V. Cadmium toxicity to rainbow trout, Salmo gairdneri Richardson. A study of eggs and alevins. J. Fish Biol.1982; 21: 47-57

[27] Soylak M, Elci L. Solid phase extraction of trace metal ions in drinking water samples from KayseriTurkey. J. Trace Micro. Techn. 2000; (18) 3: 397-403

[28] Soylak M, Dogan M. Physical and ChemicalProperties of Mineral Spring Waters from the Central Region of Anatolia, Turkey. Fresenius Environ. Bull. 1995; (4)1: 35-40

[29]Tuzen M, Soylak M, Parlar K. Cadmium and lead contamination in tap water samples from Tokat, Turkey. Bull. Environ. Contam. Tox. 2005; (75)2: 284289. 